PROCEDIA

Studi Kasus dan Intervensi Psikologi

ISSN:2302-1462; e-ISSN: 2722-7669

Volume 8(4) 161-169, Desember 2020

DOI: $10.22219 /$ procedia.v8i4.14787

\title{
Terapi keluarga untuk memperbaiki pola komunikasi orang tua dan anak
}

Annisa Ariani, Universitas Muhammadiyah Malang, Malang, Indonesia

Korespondonesi:

Annisa Ariani, email: annisaarianii@gmail.com

\begin{abstract}
Riwayat artikel
Naskah diterima:

01/09/2020

Revisi diterima:

14/11/2020

Naskah disetujui:

03/12/2020
\end{abstract}

\begin{abstract}
Abstrak
Komunikasi antara orang tua dan anak merupakan hal yang penting dalam keluarga. Masalah yang terjadi pada kasus ini yaitu komunikasi yang tidak efektif antara anak dan orang tua yang dikarenakan tidak terjalinnya komunikasi secara langsung sehingga membentuk pola perilaku yang berulang. Seluruh anggota keluarga hanya memendam pemikirannya masing-masing. Anggota keluarga tidak ada yang menyampaikan pendapatnya secara terbuka dan mencoba untuk menyelesaikan masalah yang terjadi di dalam keluarga. Pola asuh yang diterapkan dalam keluarga ini adalah otoriter. Permasalahan tersebut dapat ditangani dengan intervensi terapi keluarga yang mana terapi ini berfokus pada kondisi sekarang dan perubahan tingkah laku. Hasil intervensi terapi keluarga yang telah diterapkan dapat memperbaiki pola komunikasi antara orang tua dan anak. Anggota keluarga mencoba untuk mengkomunikasikan dengan baik dan tidak memilih untuk memendam masalah sehingga masing-masing anggota keluarga mampu membentuk perilaku baru yang telah disepakati.

Kata kunci: pola komunikasi, terapi keluarga, orang tua, anak.
\end{abstract}

\section{Latar Belakang}

Keluarga merupakan unit utama masing-masing anggota untuk berkembang baik secara fisik, emosi, spriritual, dan sosial (Lestari, 2012). Keluarga menjadi tempat anak untuk memulai kehidupan, mendapatkan pengajaran tentang nilai, moral dan agama. Anak-anak yang harmonis terlahir dari keluarga yang harmonis, begitupun anak-anak yang tidak harmonis terlahir dari keluarga yang tidak harmonis (Kardinah, 2018). Pembentukan karakter anak di masa depan berawal dari keluarga, seperti pendidikan moral dan kejujuran yang diajarkan sejak dini (Agustin et al, 2015). Keluarga dapat berjalan sesuai dengan peran dan fungsinya, jika anggota keluarga di dalamnya berperan menurut fungsinya masing-masing serta mampu menyikapi masalah yang 
sering kali menghampiri (Astutik, 2013). Keluarga adalah suatu unit yang berfungsi sesuai atau tidak sesuai menurut tingkat persepsi peran dan interaksi di antara peran dari anggota (Wahyu, 2017).

Keterampilan dalam berkomunikasi dapat membuat pola hubungan yang baik antar anggota keluarga, namun apabila komunikasi tidak terjalin dengan baik maka dapat menimbulkan kesalahpahaman dan perbedaan persepsi bagi lawan bicara serta menimbulkan respon yang berbeda (Lestari, 2012). Kesalahpahaman dalam berkomunikasi dapat pula menimbulkan konflik yang terjadi karena menggunakan gaya komunikasi yang salah. Setiap keluarga, terdapat konflik antara orang tua dan anak yang tidak dapat dihindari, konflik tersebut diidentifikasikan sebagai suatu perselisihan dan argumen yang menentang satu sama lain (Nelson et al, 2014). Komunikasi dalam sebuah keluarga merupakan suatu hal yang penting karena hal tersebut membantu dalam pengembangan keintiman dan kemampuan untuk beradaptasi antar anggota keluarga (Dai \& Wang, 2015). Hal tersebut dapat disimpulkan bahwa apabila dalam sebuah keluarga tidak terjalin komunikasi yang efektif maka akan terjadi masalah dalam keluarga tersebut.

Komunikasi efektif dapat dilakukan dengan 5 cara yaitu positivity yaitu bersikap baik, sopan, dan ceria selama percakapan. Openess, keterbukaan yang melibatkan terjalinnya diskusi antara hubungan berbagai pemikiran dan perasaan. Assurances, jaminan yang melibatkan ekspresi cinta dan komitmen. Social networks, menyangkut terkait menghabiskan waktu bersama baik keluarga ataupun teman. Sharing tasks, saling terlibat dalam pekerjaan rumah tangga serta apapun yang merupakan tanggungjawab pasangan (Canary, Stafford, \& Semic, 2002). Komunikasi keluarga merupakan proses penyampaian informasi secara terbuka dalam keluarga, baik informasi yang menyenangkan ataupun yang tidak menyenangkan. Selain itu, komunikasi keluarga juga dapat membantu menyelesaikan masalah dalam keluarga dengan cara berbicara secara jujur, terbuka, dan sabar (Hargie et al, 2004).

Tujuan komunikasi dalam interaksi keluarga ditinjau dari kepentingan orang tua adalah untuk memberikan informasi, nasihat, mendidik dan menyenangkan anak-anak. Anak berkomunikasi dengan orang tua untuk mendapatkan saran, nasihat, masukan dalam memberikan respon dari pertanyaan orang tua. Komunikasi antar anggota keluarga dilakukan agar terjadi keharmonisan dalam keluarga. Setiap komunikasi yang dilakukan dalam keluarga dapat membuat perubahan perilaku anggota keluarga, sehingga apapun masalahnya sebaiknya dibicarakan secara baik-baik untuk mendapatkan solusi yang baik juga (Wahyu, 2017).

Permasalahan yang dialami subjek saat ini adalah adanya pola komunikasi yang tidak efektif antara anak pertama dan orang tua. Anak mengatakan bahwa ibu sering marah-marah ketika di rumah. Anak sering melihat ibu memarahi nenek dan ayahnya sehingga membuat anak membenci ibunya. Anak mengatakan bahwa ibu memarahi dan memukul tanpa mau mendengarkan cerita anak terlebih dahulu. Ibu jarang mengajak anak untuk berkomunikasi karena menyadari bahwa anaknya tidak menyukainya, sedangkan ayah hanya diam ketika ibu sering memarahi anaknya sehingga anak menganggap bahwa peran ibu sebagai wanita lemah lembut dan ayah yang tegas dalam keluarga tidak berfungsi.

Berdasarkan dari permasalahan tersebut, intervensi yang dapat diberikan untuk permasalahan komunikasi yang dialami oleh subjek saat ini adalah terapi keluarga. Hasil penelitian sebelumnya mengatakan bahwa terapi keluarga dapat meningkatkan dan menciptakan pola komunikasi yang baik dalam keluarga. Terapi keluarga yang diberikan kepada keluarga subjek selama empat sesi membuat hubungan komunikasi antara anggota keluarga satu sama lainnya menjadi lebih baik, di antaranya yaitu menjadi terbuka dengan keluh kesah masing-masing anggota keluarga yang dipendam, selain itu masing-masing anggota keluarga mampu membentuk perilaku baru yang telah disepakati walaupun dari beberapa tugas rumah belum dilakukan (Wahyu, 2017). Pada kasus ini, terapi keluarga yang merupakan terapi 
berfokus pada keadaan sekarang dan perubahan tingkah laku dilakukan dengan 7 sesi yaitu social stage, problem stage, interaction stage, defining desired change, ending the interview, evaluasi perubahan dan terminasi.

\section{Metode Assesmen}

Metode asesemen yang digunakan untuk menegakkan diagnosa dalam kasus ini adalah wawancara, observasi dan skala pola asuh. Wawancara dilakukan kepada ayah, ibu, dan anak pertama untuk mengetahui dinamika permasalahan yang dialami dalam keluarga. Observasi dilakukan untuk mengetahui pola komunikasi dan interaksi yang terjalin dalam keluarga. Skala pola asuh digunakan untuk melihat pola asuh yang diberikan oleh orang tua kepada anak.

\section{Presentasi Kasus}

Anggota keluarga terdiri dari ayah, ibu dan dua orang anak perempuan. Ayah berusia 43 tahun bekerja sebagai satpam, ibu 41 tahun merupakan pegawai pabrik dan dua orang anak perempuan yang berusia 20 tahun dan 17 tahun. Orang tua cenderung menuntut anak untuk mengikuti keinginan keluarga. Orang tua selalu ingin mengarahkan setiap tindakan yang dilakukan oleh anak. Sementara itu, dalam keluarga tidak ada aturan tertentu yang dibuat oleh anggota keluarga untuk disepakati dan dilaksanakan bersama, orang tua hanya memberikan arahan cara berperilaku yang baik menurut mereka tanpa memberikan pemahaman yang tepat pada anak.

Sejak kecil, anak pertama diasuh oleh kakek dan neneknya dikarenakan orang tua yang sibuk bekerja. Anak pertama sangat dekat dengan sosok neneknya yang sering dimarahi oleh ibunya. Anak pertama juga sering dimarahi oleh ibunya jika tidak bisa memahami pelajaran yang diajarkan. Sejak anaknya masih kecil, ibu sibuk dengan pekerjaannya hingga pulang dari bekerja pada sore hari.

Lelah yang dirasakan ibu sepulang bekerja, membuatnya sering marah-marah kepada anak-anak dan suaminya dengan menggunakan kata-kata kasar. Anak pertama tidak betah ketika berada di rumah sehingga sering bermain bersama temannya dan mengerjakan tugas bersama temannya di luar rumah sampai larut malam. Ibu memarahinya dengan kata-kata kasar dan tidak mau mendengarkan penjelasan mengenai kegiatan yang dilakukannnya di luar rumah yang membuatnya sampai pulang larut malam. Ibu juga menceritakan kepada tetangga bahwa anaknya pulang tengah malam dan menceritakan bahwa kelakuan nakal anaknya dikarenakan lingkungan pertemanan yang tidak baik serta mencari pemecahan masalahnya dengan tetangga nya yang merupakan keluarga ibu. Anak membenci sikap ibunya dan kesal dengan ayahnya dikarenakan ayah tidak melakukan perannya sebagai kepala keluarga yang tegas. Hal tersebut menyebabkan ibu mendominasi di dalam keluarga, sehingga adanya peran yang kabur dan tidak ada pendirian pada ayah dalam keluarga.

Anak tidak ingin memakan masakan ibunya dan tidak mau membantu kegiatan ibu di rumah. Ayah tidak mengetahui bagaimana cara mendamaikan istri dan anak pertamanya dikarenakan kepribadian mereka yang sama-sama keras kepala sehingga ayah hanya mendiamkan keadaan tersebut. Anak membenci ibunya hingga ketika mendengar suara ibu akan pusing, mual, dan tidak nyaman berada di rumah. Anak pernah ada keinginan untuk membunuh ibunya dikarenakan ibu yang selalu marah-marah dan mengucapkan kata-kata kasar ketika di rumah. Selama ini ibu sering meminta maaf ketika lebaran kepada semua keluarga, namun demikian hal tersebut tidak merubah sikap ibu nya terhadap keluarga. Ibu sering mengulang perlakuan kasarnya terhadap keluarga sehingga anak semakin membenci ibunya. Pola asuh yang diterapkan dalam keluarga adalah otoriter.

Ibu menginginkan anak yang patuh dan hormat terhadap orang tua, namun anak sering bertingkah acuh tak acuh terhadap keluarga ibu yang merupakan tetangga mereka sehingga membuat ibu kesal terhadap anaknya. Ibu menyadari bahwa anak tidak menyukainya sehingga 
ketika anak berada di rumah, ibunya jarang untuk mengajak berbicara dan membiarkan anaknya mengurung diri di dalam kamar. Ayah menyadari bahwa anaknya membenci ibunya dan pernah terlihat ingin berniat jahat kepada ibunya, namun ayah bingung harus melakukan apa karena ibu dan anak merupakan orang yang sama-sama keras kepala.

Anak berpikir bahwa semua ibu menyayangi anaknya berbeda dengan ibunya yang menurutnya jahat sehingga dapat membuat dirinya dan ibunya bermusuhan. Anak merasa bahwa ayahnya jarang memarahi ibunya. Anak berharap ayahnya berubah menjadi lebih tegas terhadap ibunya karena merasa ayahnya merupakan orang yang tidak tegas. Anak menganggap keluarganya berantakan jika dibandingkan dengan keluarga lainnya dimana keluarganya memperlakukannya seperti orang asing.

Permasalahan yang terjadi adalah pola komunikasi yang tidak efektif antara orang tua dan anak yaitu tidak terjalinnya komunikasi secara langsung hal ini disebut cybernatics, bagaimana sistem pemrosesan informasi dikarenakan umpan balik sehingga membuat keluarga menjadi bermasalah. Komunikasi adalah interaksi yang terjadi antara dua orang atau lebih yang saling memiliki kesamaan makna terkait hal yang sedang dikomunikasikan, selain itu komunikasi juga berfungsi untuk menyampaikan informasi dan komunikasi yang efektif dapat terjadi apabila informasi yang disampaikan dapat dipahami oleh si penerima informasi (Andjani, 2014).

Komunikasi interpersonal dalam keluarga sangat penting karena dengan adanya komunikasi interpersonal antar sesama anggota keluarga maka akan tercipta hubungan yang harmonis dan dapat diketahui apa yang diinginkan dan yang tidak diinginkan oleh salah satu anggota keluarga. Komunikasi interpersonal dalam keluarga yaitu hubungan timbal balik antara anggota keluarga untuk berbagi berbagai hal dan makna dalam keluarga. Tujuan dari komunikasi interpersonal dalam keluarga yaitu untuk mengetahui dunia luar dan untuk mengubah sikap dan perilaku, oleh karena itu dengan melakukan komunikasi interpersonal yang baik diharapkan perkembangan pemahaman moral akan berjalan baik pada anak (Wahyu, 2017).

Komunikasi yang terjadi dalam keluarga subjek tidak efektif dikarenakan tidak terjalinnya komunikasi secara langsung sehingga membentuk pola perilaku yang berulang atau disebut cybernatics. Semua anggota keluarga hanya memendam pemikirannya masing-masing. Anggota keluarga tidak ada yang menyampaikan pendapatnya secara terbuka dan mencoba untuk menyelesaikan masalah yang terjadi di dalam keluarga.

Ibu marah-marah ketika pulang bekerja, namun ayah hanya mendiamkannya dan membuat ibu semakin marah. Hal tersebut membuat anak membenci ibunya. Ayah mengetahui keadaan tersebut bingung harus melakukan apa dan tidak mencoba untuk mengajak berbicara anaknya sehingga anaknya semakin tidak menyukai keluarganya dan melakukan kegiatan yang melanggar peraturan di rumah. Hal tersebut membuat ibunya kembali marah-marah dengan tingkah laku anaknya.

Pola komunikasi yang bermasalah antara anak dan orang tua adalah tidak terjalinnya komunikasi secara langsung atau disebut juga sebagai indirect communication. Anak tidak menjelaskan kepada ibu mengenai alasan kebenciannya terhadap ibunya secara langsung, tetapi hanya menunjukkan dengan sikap tidak hormat sehingga membuat dirinya semakin kesal dengan ibunya. Hal ini pun dilakukan oleh ibu yang tidak mengkomunikasikan secara langsung alasan anaknya membencinya dan hanya membiarkan anaknya berada di dalam kamar ketika di rumah. Ayah mengetahui anaknya membenci ibunya namun tidak tahu caranya untuk mengkomunikasikan langsung antara ibu dan anaknya sehingga hanya mendiamkan ibu dan anaknya.

Intervensi yang dapat diberikan adalah terapi keluarga dengan tujuan untuk memperbaiki pola komunikasi yang terjalin antara ayah, ibu dan anak. Beberapa penelitian menjelaskan bahwa terapi keluarga dapat meningkatkan dan menciptakan pola komunikasi yang baik dalam keluarga (Wahyu, 2017). Terapi keluarga dapat membantu keluarga memperbaiki pola 
komunikasi yang sebelumnya terhambat. Beberapa hasil positif adalah orang tua merasa mendapatkan pengetahuan dan keterampilan bagaimana menjalin pola komunikasi yang efektif dengan anaknya (Martiningtyas \& Paramastri, 2015)..

\section{Diagnosis dan Prognosis}

Berdasarkan hasil asesmen yang telah dilakukan, diagnosis yang didapatkan yaitu pola komunikasi yang tidak efektif. Pola komunikasi yang bermasalah antara anak dan orang tua terjadi secara berulang dan memutar. Ibu marah-marah saat pulang bekerja, namun ayah hanya mendiamkannya sehingga ibu semakin marah. Hal tersebut membuat anak membenci ibunya. Ayah mengetahui keadaan tersebut bingung harus melakukan apa dan tidak mencoba untuk mengajak berbicara anaknya sehingga anaknya semakin tidak menyukai keluarganya serta melakukan kegiatan yang melanggar peraturan di rumah. Hal tersebut membuat ibunya semakin marah-marah dengan tingkah laku anaknya. Prognosis pada anggota keluarga yaitu baik. Hal ini dapat dilihat dari keluarga yang kooperatif dalam memberikan informasi, dapat bekerjasama dengan baik, dan adanya keinginan untuk berubah menjadi lebih baik

\section{Intervensi}

Target dari terapi keluarga adalah untuk memperbaiki pola komunikasi orang tua dan anak yang tidak efektif dimana tidak terjalinnya komunikasi secara langsung yang efektif. Keberhasilan dari terapi ini yaitu terciptanya komunikasi yang efektif dimana anggota keluarga dapat menyampaikan keluhan dan harapannya masing-masing serta membentuk perilaku baru sebagai solusi untuk menyelesaikan permasalahan yang terjadi.

Terapi keluarga adalah terapi yang berorientasi pada aktivitas terapis dimana pada terapi ini terapis yang bertanggung jawab membangun strategi perubahan pada klien. Masalah interpersonal dalam keluarga dijelaskan oleh model sebab akibat. Terapi keluarga harus mempertimbangkan sistem individualitas dan keadaan yang berhubungan dengannya (Devi, 2016). Terapi keluarga berfokus pada keadaan sekarang dan perubahan perilaku. Berdasarkan kasus di atas, dapat diketahui bahwa perilaku yang akan diubah adalah membuat orang tua dan anak agar dapat mengkomunikasikan secara langsung apabila ada sesuatu hal yang tidak disenangi begitupun perilaku yang harus diubah dari masing-masing anggota dengan tujuan agar dapat membangun keluarga yang lebih baik lagi antara orang tua dan anak. Perubahan yang diharapkan dalam terapi ini adalah dapat merubah pola interaksi negatif menjadi interaksi positif dalam keluarga, yang mengarah pada diri individu itu sendiri dan cara menyelesaikan masalah. Terapi ini berfokus untuk membuat keluarga dapat menyelesaikan masalah dengan sendirinya dan menciptakan masa depan yang lebih baik. Masalah yang terjadi dalam keluarga tidak terjadi secara acak tetapi bergantung pada siklus perkembangan keluarga.

Prosedur terapi keluarga adalah social stage yaitu menghadirkan seluruh anggota keluarga dimana setiap keluarga diminta untuk memberikan pendapat yang dihadapi. The problem stage yaitu menjelaskan kepada keluarga alasan kenapa mereka harus hadir, memberikan kesempatan kepada masing-masing keluarga untuk berbicara dimulai pada anggota keluarga yang netral. Interaction stage yaitu meminta komentar dari setiap anggota keluarga yang hadir kemudian meminta keluarga untuk membicarakan masalah bersama-sama, dilanjutkan defining desired changes yaitu terapis menyampaikan permasalahannya, setelah semua anggota keluarga mengetahui permasalahan yang terjadi kemudian terapis menanyakan perubahan seperti apa yang diharapkan. Ending the interview yaitu setelah dicapai kesepakatan bersama mengenai definisi masalah, kemudian melanjutkan pada sesi pertemuan selanjutnya evaluasi perubahan dan pemberian tugas dan sesi terakhir terminasi (Wahyu, 2017). Sesi terapi keluarga yang dilakukan pada kasus ini adalah sebagai berikut: 
Sesi 1: Social Stage Pada sesi social stage, terapis memperkenalkan diri dan perannya sebagai seorang terapis. Terapis membangun raport pada anggota keluarga agar merasa nyaman mengikuti terapi dan memberikan gambaran terkait proses yang akan dilakukan selanjutnya. Terapis memberikan pertanyaan kepada masing-masing anggota keluarga dan terapis tidak memihak kepada siapapun. Tujuan pada sesi social stage adalah untuk mengetahui pendapat mengenai masalah dalam keluarga.

Sesi 2: Problem Stage Pada sesi kedua yaitu problem stage, terapis melakukan penggalian masalah secara detail kepada setiap anggota dan tidak memberikan saran. Tujuan pada sesi problem stage adalah menggali masalah secara lebih detail terhadap seluruh anggota keluarga.

Sesi 3: Interaction Stage Sesi ketiga yaitu interaction stage, terapis dan seluruh anggota keluarga bersama-sama membicarakan permasalahan yang terjadi dalam keluarga kemudian mencari tahu pola interaksi yang salah. Tujuan dari sesi ini adalah dapat melihat pola interaksi yang salah.

Sesi 4: Defining Desired Change Pada sesi defining desired changes, terapis mendefinisikan masalah secara konkrit berdasarkan yang didapat pada sesi sebelumnya. Terapis kemudian mengajak keluarga untuk mencari kesepakatan mengenai perubahan yang diharapkan. Tujuan pada sesi ini adalah anggota keluarga dapat mendefinisikan masalah secara bersama-sama dan mencari kesepakatan untuk melakukan perubahan.

Sesi 5: Ending The InterviewPada sesi ending the interview, terapis memberikan tugas-tugas yang harus dilaksanakan di luar sesi terapi untuk semua anggota keluarga. Perubahan perilaku yang diharapkan menjadi tugas masing-masing anggota untuk mencapai perubahan dalam keluarga. Terapis meminta masing-masing anggota sampai pertemuan selanjutnya melaporkan dengan menggunakan teknik directives berupa daftar checklist yang bertujuan untuk membuat anggota keluarga melakukan sesuatu yang berbeda dan merasakan pengalaman yang berbeda.

Sesi 6: Evaluasi Perubahan Pada sesi ini, terapis melakukan evaluasi terhadap perubahan pada sesi sebelumnya apakah dapat diterapkan dalam keluarga untuk memperbaiki hubungan dalam keluarga dan melihat kelebihan serta kekurangan setiap anggota dalam melaksanakan tugasnya. Terapis memberikan saran agar masing-masing anggota dapat saling membangun komunikasi dengan baik antar anggota. Tujuan dari sesi ini adalah untuk melihat perubahan-perubahan telah terjadi pada tiap anggota keluarga.

Sesi 7: Terminasi Pada sesi ini, terapis melakukan pemberhentian terapi dan memberikan dukungan. Terapis memberikan evaluasi pada keseluruhan sesi yang telah dilakukan. Terapis menanyakan perasaan antar anggota setelah melakukan terapi dan membahas manfaat yang didapatkan selama proses terapi kemudian terapis menyimpulkan kegiatan terapi dari awal sampai akhir.

\section{Hasil dan Pembahasan}

\section{Hasil}

Hasil dari intervensi yang dilakukan dapat memperbaiki pola komunikasi orang tua dan anak. Pola komunikasi yang bermasalah antara anak dan orang tua adalah tidak terjalinnya komunikasi secara langsung yang disebut dengan indirect communication. Anak tidak menjelaskan kepada ibu mengenai alasan kebenciannya terhadap ibunya secara langsung, hanya menunjukkan dengan sikap tidak patuh sehingga membuat dirinya semakin kesal dengan ibunya. Hal ini juga dilakukan oleh orang tua, ibu tidak mengkomunikasikan secara langsung alasan anaknya membencinya dan hanya membiarkan anaknya berada di dalam kamar ketika di rumah. Ayah mengetahui anaknya membenci ibunya namun tidak mengkomunikasikan secara langsung kepada ibu dan anaknya. 
Hasil setelah dilakukan terapi keluarga, pola komunikasi antara anak dan orang tua semakin terbuka. Anak dan orang tua saling mengkomunikasikan langsung mengenai apa saja yang selama ini dipendam masing-masing anggota. Anak mengetahui bahwa orang tuanya sangat menyayangi dirinya dan ibu nya menyesal karena sikap nya yang sering marah-marah kepada keluarga. Ibu meminta maaf kepada anaknya, ibu memberikan penjelasan bahwa dirinya kelelahan setelah pulang bekerja sehingga sering marah-marah. Ayah biasanya hanya membiarkan ibu dan anaknya, mencoba untuk memberikan pesan kepada anak dan istrinya untuk ke depannya setelah dilakukan terapi (hasilnya dapat dilihat pada Tabel 1.

Terapi keluarga yang diberikan kepada keluarga subjek selama tujuh sesi membuat hubungan komunikasi antara anggota keluarga satu sama lainnya menjadi lebih baik, di antaranya yaitu menjadi lebih terbuka, mengetahui keluhan dan memenuhi harapan masing-masing anggota yang selama ini dipendam, selain itu masing-masing anggota keluarga mampu membentuk perilaku baru yang telah disepakati. Subjek mengalami perubahan berupa komunikasi yang efektif antara orang tua dan anak setelah menjalani rangkaian intervensi terapi keluarga. Perubahan dapat dilihat dari yang sebelum terapi dilakukan orang tua dan anak tidak memiliki komunikasi yang baik, adanya pandangan dan kesalahpahaman antara orang tua dan anak serta kurangnya kesempatan untuk berinteraksi, setelah dilakukan terapi perilaku baru yang ditunjukkan oleh keluarga antara lain anak melakukan tugasnya yaitu menyapu rumah, membantu ibu memasak di dapur, dan berbicara dengan orang tua di ruang televisi. Ibu melakukan tugas yaitu mengajak anak untuk creambath di salon bersama dan berkunjung ke rumah saudara. Ayah mengajak

Tabel 1. Perubahan Pola Komunikasi dan Perilaku Sebelum dan Setelah Intervensi

\begin{tabular}{ll}
\hline Sebelum intervensi & Setelah intervensi \\
\hline
\end{tabular}

\section{Pola Komunikasi}

Anak dan orang tua jarang berinteraksi di rumah dikarenakan anak hanya mengurung diri di kamar jika berada di rumah.

Ibu sering kesal dengan tingkah laku anak dan memarahi ayah.

Ayah hanya mendiamkan tingkah laku anak dan ibu.

\section{Perilaku}

Anak membenci ibunya sehingga tidak ingin pulang ke rumah.

Anak tidak mau memakan masakan ibu. Anak tidak hormat dengan orang tua.

Ibu menceritakan perilaku negatif anak ke tetangga.

Ibu marah-marah saat pulang bekerja.

Ayah sering bingung harus melakukan apa.

Sosok peran ayah kabur dalam keluarga.
Anak dan orang tua sering berinteraksi dan melakukan kegiatan bersama di rumah.

Masing-masing anggota keluarga saling berbicara dari hati ke hati sehingga masing-masing keluarga dapat memaafkan kesalahan masing-masing. Masing-masing anggota bersedia untuk ditegur jika melakukan kesalahan yang sama.

Anak tinggal di rumah ketika libur kuliah.

Anak membantu ibu memasak di dapur. Anak menuruti perintah orang tua.

Ibu mengajak anak untuk bertamu ke rumah keluarga.

Ibu mengontrol emosinya ketika dalam keadaan lelah.

Ayah sering mengajak diskusi anak dan istri.

Ayah sering memberikan ceramah pada keluarga. 
keluarga untuk liburan ketika hari libur dan memberikan nasihat pada keluarga. Berdasarkan hasil tersebut, dapat dikatakan bahwa orang tua dan anak mampu membentuk sebuah perilaku sebagai solusi untuk menyelesaikan permasalahan yang terjadi dan disepakati secara bersama.

Perubahan yang terjadi antara orang tua dan anak berdampak pada pola komunikasi antara orang tua dan anak. Perubahan berupa komunikasi yang efektif antara orang tua dan anak. Mereka saling mengetahui pandangan dan keinginan masing-masing sehingga adanya solusi untuk memperbaiki interaksi dan memahami kebutuhan dan peranan masing-masing. Hal ini menandakan bahwa terapi keluarga mampu memperbaiki pola komunikasi orang tua dan anak yang tidak efektif menjadi efektif.

\section{Pembahasan}

Hasil intervensi menunjukkan bahwa terapi keluarga dapat memperbaiki pola komunikasi orang tua dan anak. Pola komunikasi tidak efektif yang terjadi dalam kasus ini menyebabkan anak tidak mau pulang ke rumah dan membenci ibunya. Hal ini dikarenakan tidak terjalinnya komunikasi secara langsung sehingga membentuk pola yang berulang. Tidak adanya anggota keluarga yang menyampaikan keluhan dan harapannya secara terbuka serta mendiskusikan di dalam keluarga menyebabkan pola komunikasi yang tidak efektif. Seluruh keluarga dapat menyampaikan pendapatnya mengenai masalah yang sedang terjadi pada saat sesi terapi berlangsung.

Terapis dan seluruh subjek dapat menggali masalah lebih detil mengenai anak yang tidak menyukai ibunya dikarenakan ibunya sering marah-marah. Ibu yang awalnya menganggap bahwa anaknya nakal karena pergaulan teman-temannya, setelah dilakukan intervensi mengetahui bahwa anaknya membenci dirinya dikarenakan dirinya sendiri dan ayah yang tidak dapat menjadi sosok tegas dalam keluarga menyebabkan adanya permasalahan dalam hal komunikasi dan kurangnya kesempatan untuk berinteraksi. Orang tua dan anak menjadi menyadari bahwa selama ini interaksi di dalam keluarga tidak efektif. Anggota keluarga mendefinisikan masalah secara bersama-sama dan mencari kesepakatan untuk melakukan perubahan. Anak termotivasi untuk melakukan tugasnya yaitu menyapu rumah, membantu ibu memasak di dapur, serta berbicara dengan orang tua di ruang televisi. Ibu melakukan tugasnya yaitu mengajak anak untuk creambath di salon bersama dan berkunjung ke rumah keluarga. Ayah termotivasi untuk melakukan tugasnya yaitu mengajak keluarga untuk liburan ketika hari libur. Anggota keluarga mengikuti seluruh sesi dalam terapi yang membuat hubungan komunikasi yang dibina berjalan dengan baik.

Terapi keluarga merupakan intervensi yang cocok digunakan untuk memperbaiki komunikasi dalam keluarga (Wahyu, 2017) (Martiningtyas \& Paramastri, 2015). Terapi keluarga mentargetkan pola interaksi maladaptif yang terjadi berulang-ulang dalam keluarga yang diberikan bertujuan untuk memperbaiki komunikasi antar anggota keluarga sehingga keluhan dan harapan dapat terpenuhi (Martiningtyas \& Paramastri, 2015). Terapi keluarga yang sesuai untuk meningkatkan komunikasi orang tua dan anak dalam keluarga berhubungan dengan terapi yang dilakukan pada kasus ini dimana pola komunikasi yang tidak langsung di dalam keluarga terjadi berulang-ulang, sehingga intervensi dapat berjalan dengan baik pada kasus ini.

Terapi keluarga yang dilakukan pada kasus ini menggunakan strategi yang sudah dirancang dan dilaksanakan sesuai prosedur. Terapi keluarga yang diberikan kepada subjek dibuat bersama-sama oleh anggota keluarga. Terapi keluarga ini berfokus pada konsep behavior, artinya tujuan keluarga tersebut merupakan perilaku yang nampak atau dapat diobservasi. Perilaku yang diinginkan mengikuti konsep behavioral dalam arti perilaku yang diinginkan pada akhir proses terapi, merupakan perilaku yang dapat berubah dalam konteks yang masuk akal atau perilaku yang masih dapat diperhitungkan. Tugas yang dirancang untuk anggota keluarga menggunakan teknik directive oleh Haley berupa daftar checklist yang bertujuan untuk membuat 
anggota keluarga melakukan sesuatu yang berbeda dan merasakan pengalaman yang berbeda (Wahyu, 2017). Tugas yang dilakukan pada kasus ini, anak membuat daftar checklist yaitu pulang ke rumah pada saat liburan, membantu ibu memasak di dapur, menyapu rumah, dan berbicara dengan orang tua. Ibu membuat daftar checklist yaitu mengajak melakukan aktivitas bersama anak di luar rumah. Ayah membuat checklist yaitu mengajak liburan keluarga.

\section{Simpulan}

Terapi keluarga dapat memperbaiki pola komunikasi orang tua dan anak. Permasalahan dalam keluarga subjek dikarenakan masing-masing anggota memilih untuk diam daripada mendiskusikan masalah yang ada, sehingga komunikasi antar anggota keluarga tidak terjalin dengan baik. Intervensi yang diberikan adalah terapi keluarga dengan tujuan untuk menghasilkan komunikasi yang efektif di dalam keluarga. Keluarga yang memiliki masalah sebaiknya segera mengkomunikasikan dengan baik mengenai solusi dan tidak memilih untuk memendam masalah tersebut sehingga masing-masing anggota keluarga mampu membentuk perilaku baru yang telah disepakati. Saran yang diberikan kepada masing-masing anggota keluarga adalah anggota keluarga dapat mengaplikasikan tugas-tugas rumah dan saling memahami kondisi satu sama lain.

\section{Referensi}

Agustin, D. S. Y., Suarmini, N. W., \& Prabowo, S. (2015). Peran keluarga sangat penting dalam pendidikan mental, karakter anak serta budi pekerti anak. Jurnal Sosial Humaniora, 8(1), 46. https://doi.org/10.12962/j24433527.v8i1.1241.

Andjani, M. dan M. D. (2014). Komunikasi antarpribadi dalam masyarakat majemuk. Dapur Buku.

Astutik, S. (2013). Family therapy dalam menangani pola asuh orang tua yang salah pada anak slow learner. Jurnal Bimbingan Dan Konseling Islam, 03(01), 17-35.

Canary, D. J., Stafford, L., B, L, \& Semic, E. A. (2002). A panel study of the associations between maintenance strategies and relational characteristics. Journal of Marriage and Family, 64, 395-406.

Dai, L., \& Wang, L. (2015). Review of family functioning. Open Journal of Social Sciences, 03(12), $134-141$. https://doi.org/10.4236/jss.2015.312014.

Devi, D. F. (2016). Mengatasi masalah komunikasi dalam keluarga melalui strategic family therapy. Jurnal Intervensi Psikologi (JIP), 8(2), 234-249. https://doi.org/10.20885/intervensipsikologi.vol8.iss2.art6.

Hargie, O., Dickson, D., \& Tourish, D. (2004). Communication skills for effective management. Palgrave Macmillan.

Kardinah, N. (2018). Keluarga dan problematikanya menuju keluarga sakinah (tinjauan dalam persfektif marrital psikologi). Psympathic: Jurnal Ilmiah Psikologi, 1(1), 109-120. https://doi.org/10.15575/psy.v1i1.2171.

Lestari, S. (2012). Psikologi keluarga penanaman nilai dan penanganan konflik dalam keluarga. Kencana.

Martiningtyas, M. A. D., \& Paramastri, I. (2015). Penerapan brief strategic family therapy (bsft) untuk meningkatkan komunikasi orang tua-anak. Gadjah Mada Journal Of Professional Psychology, 1(1), 64-75.

Nelson, J. A., O'Brien, M., Grimm, K. J., \& Leerkes, E. M. (2014). Identifying mother-child interaction styles using a person-centered approach. Social Development, 23(2), 306-324. https://doi.org/10.1111/sode.12040.

Wahyu, U. (2017). Strategic family therapy untuk memperbaiki komunikasi dalam keluarga di Nganjuk. Journal An-Nafs, 2(2), 140-153. 